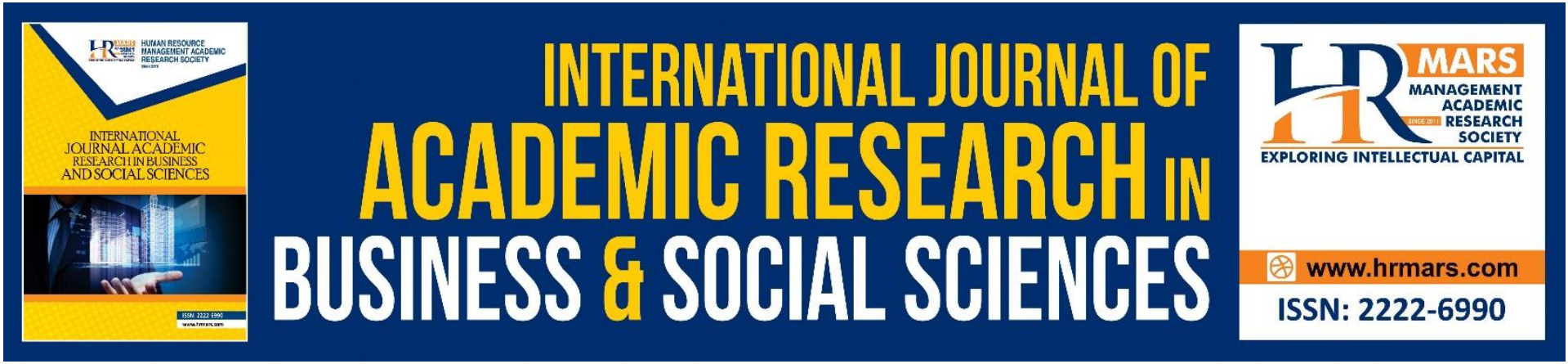

\title{
To Change or Not to Change: Does it Affect my School?
}

Iskandar Padzil, Suhaida Abdul Kadir, Ahmad Fauzi Mohd Ayub and Mohd Mursyid Arshad

To Link this Article: http://dx.doi.org/10.6007/IJARBSS/v11-i12/11897

DOI:10.6007/IJARBSS/v11-i12/11897

Received: 16 October 2021, Revised: 21 November 2021, Accepted: 30 November 2021

Published Online: 18 December 2021

In-Text Citation: (Padzil et al., 2021)

To Cite this Article: Padzil, I., Kadir, S. A., Ayub, A. F. M., \& Arshad, M. M. (2021). To Change or Not to Change: Does it Affect my School? International Journal of Academic Research in Business and Social Sciences, 11(12), 1692-1708.

\section{Copyright: @ 2021 The Author(s)}

Published by Human Resource Management Academic Research Society (www.hrmars.com)

This article is published under the Creative Commons Attribution (CC BY 4.0) license. Anyone may reproduce, distribute, translate and create derivative works of this article (for both commercial and non0-commercial purposes), subject to full attribution to the original publication and authors. The full terms of this license may be seen

at: http://creativecommons.org/licences/by/4.0/legalcode

Vol. 11, No. 12, 2021, Pg. $1692-1708$

http://hrmars.com/index.php/pages/detail/IJARBSS

JOURNAL HOMEPAGE

Full Terms \& Conditions of access and use can be found at http://hrmars.com/index.php/pages/detail/publication-ethics 


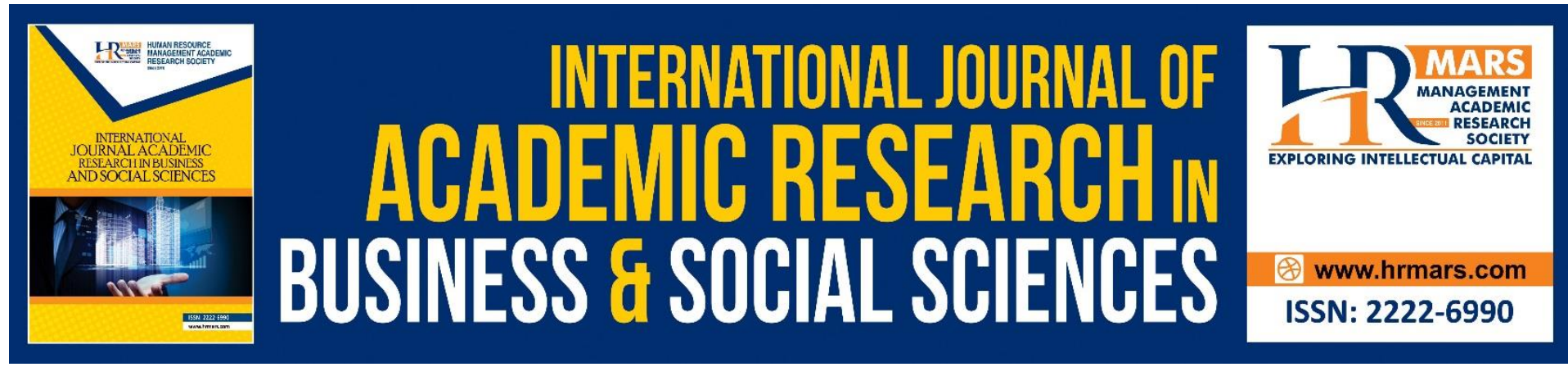

\title{
To Change or Not to Change: Does it Affect my School?
}

\section{${ }^{1}$ Iskandar Padzil, ${ }^{1}$ Suhaida Abdul Kadir, ${ }^{2}$ Ahmad Fauzi Mohd Ayub and ${ }^{3}$ Mohd Mursyid Arshad}

${ }^{1}$ Department of Science and Technical Education, Faculty of Educational Studies, Universiti Putra Malaysia, 43400 UPM Serdang, Selangor, Malaysia, ${ }^{2}$ Department of Foundations of Education, Faculty of Educational Studies, Universiti Putra Malaysia, 43400 UPM Serdang, Selangor, Malaysia, ${ }^{3}$ Department of Professional Development and Continuing Education, Faculty of Educational Studies, Universiti Putra Malaysia, 43400 UPM Serdang, Selangor, Malaysia.

Corresponding Author: suhaida@upm.edu.my

\begin{abstract}
An effective education system needs to be developed and changed to meet current and future claims. As such, in the face of today's challenging global economic challenge, citizens with knowledge, skills and competencies are crucial to the country's success, based on highperformance education. This study aims to determine the predictors of school effectiveness in secondary schools based on the perception of the principals. Data was collected from 246 principals in low-performance schools using the survey questionnaire. The selection of the respondents based on proportionate stratified random sampling. The Structural Equation Modelling analysis showed that the model tested and evaluated was fit. Based on four constructs, namely the appropriateness of change, management support, change of efficacy and personal valence, the variance explained for school effectiveness is approximately $26.3 \%$. The findings indicated that the appropriateness of change and support for management were the main predictors of school effectiveness. The study concluded that the appropriateness of change and management support plays a vital role in the efficiency of schools among principals in low-performance schools. Changes in educational settings need to be adapted to school development to ensure that the school communities successfully adapt changes.
\end{abstract}

Keywords: School Effectiveness, Readiness for Changes, Principals, Low Performing School

\section{Introduction}

In this world, no systems remain stable. It keeps on changing in line with world development, as so in the education system. The development of an effective education system is needed to meet current and future claims (Fazel, 2013; Simendinger et al., 2017). Education is the key that underscores the vision and challenges of any institution (Ismail et al., 2011). Highly educated people will be needed to ensure that a holistic and effective process of generation of education is a reality. Quality education is, therefore, a critical factor in the development of a developed country (Deeboonmee \& Ariratana, 2014). The Ministry of Education's speech 
mandate for 2019, entitled "Education for All, Responsibility for All," set out three main directions for Malaysia's Ministry of Education. The first is to set value-based education, and the second is to improve the quality of the system as a whole. The third direction, on the other hand, relates to autonomy and accountability. The second direction emphasized quality as one of the common goals for all stakeholders in the Ministry. High quality plays a crucial role in driving excellence, relevance and effectiveness in Malaysia's education system (Amin, 2018). All parties must, therefore, move equally towards high-performance quality education (Schweinberger et al., 2017).

Malaysia's government is committed to ensuring that every school in Malaysia is of the highest quality (Iskandar et al., 2018). In line with current changes in the field of education, all school leadership aspires to the status of high-performance and quality schoo (Anthony \& van Nieuwerburgh, 2018). Therefore, to ensure the school meets the quality of highperformance schools, the process and its management require a high level of commitment on the part of all parties. Past researchers have found that there are some common characteristics in the efficiency of high-performance schools (Lezotte \& Synder, 2011). School effectiveness studies explicitly defined the school's effectiveness through variables that were considered essential to measuring the school's effectiveness (A. Harris \& Bennet, 2001). The concepts of the effectiveness of schools are broad, and researchers do not agree on the definition of the effectiveness of schools. In general, the effectiveness of the school assessed by two criteria: outcome and the process(Sharifah, 2010).

Furthermore, the concept of an effective school represents a complex problem with a variety of approaches. The first generation of studies in school effectiveness was carried out in 1966 by Lezotte and Synder (2011). This study led to studies on the effectiveness of schools. Coleman, (1966) concluded, if family background factors taken into consideration, that school has little or no effect on student achievement. Effectiveness study widely conducted in the United States, the Netherlands, Australia, and the United Kingdom (Lezotte \& Synder, 2011; Sammons et al., 2011; Scheerens, 2013). Although the study's initial focus was on student performance, researchers have opened up an entire field of school effectiveness. It includes considering other aspects such as school vision, norms and expectations, leadership, collaboration and communication, alignment with standards, monitoring of teaching and learning, professional development, learning environment, parental participation (Shannon \& Blysma, 2007), financial resources, classroom size, academic qualifications, teaching methods for classrooms and teachers (Abdul Ghani, 2008) and school achievement (Ali AlHarthi \& Hendawy Al-Mahdy, 2017; Baharak, 2015; Shih \& Tsai, 2016). The study of school effectiveness has a particular interest in Asia and third-world countries, according to the rapid development of education (Harris \& Bennet, 2001). Therefore, school effectiveness study is a comprehensive approach in the context of Malaysian culture to measure the quality of Malaysian education in line with global educational development (Arivayagan, 2015).

The findings of the study led by Shannon and Bylsma (2007) showed that the benchmarks for school effectiveness are vision, standards and expectations, leadership, collaboration and communication, standards training, teacher monitoring, professional development, the learning environment and involvement of families and communities. Lezotte and Synder (2011) have seven primary features of school effectiveness: strong educational leadership, focused mission, safe and conducive schools, high expectations of success, regular student progress surveillance, the possibility of learning something new, and good relationship with parents. In this study, however, the researcher focussed only on Shannon and Blysma (2007) listed the dimensions of school effectiveness. 


\section{The Concept of School Effectiveness}

There are different definitions of school effectiveness from multiple study angles. There is an inconsistent and definite factor that shows how effective a school is (Hajisoteriou et al., 2018). There is also no explicit agreement on the definition of school efficiency (Abdul Ghani et al., 2011; Hoy \& Miskel, 2008; Trujillo, 2018). Post-related studies have given more focus to student achievement based on race, gender and economic status (Durlak et al., 2011). School effectiveness studies should look further than academic performance and also focus on the behavioural aspects of the classroom, the participation of students and the difference of attitude towards learning (Davies \& Ellison, 1997; Harris \& Willower, 2013; Shih \& Tsai, 2016). Lezotte and Synder (2011) defined the efficacy of school as a situation which all students considered educated irrespective of their socioeconomic status or family background. A school may be founded as active unless each student demonstrates sufficient annual progress in each subgroup, but does not individually measure student achievements as set out in the No Child Left Behind Act 2001.

Defining the effectiveness of schooling depends on the diversity of factors in schools, for example, if schools have a high level of achievement (Day \& Sammons, 2014). Thus, the more efficient a school is in terms of its performance (Hallinger \& Wang, 2015; Scheerens, 2013). School efficiency depends on school parties and the resources obtained to develop a school (Reynolds, 2010). In other words, how school people are aware of the objectives outlined by using their resources without putting pressure on employers depends on the effectiveness of a school (Simendinger et al., 2017). Besides, researchers viewed the results as a measure of effectiveness; the definition of effectiveness expanded through an analysis of the improvement in school development (Alm et al., 2018). The growth of schools, or an increase in the value of school effectiveness, is taken into account by students. The effectiveness of the school is not only measured based on the achievements but also the process of improvement.

In the sense of education in Malaysia, the idea of school effectiveness focused on the views expressed in the Philosophy of National Education and Vision 2020 (Sharifah, 2010). The Malaysian Government's ambition, through Malaysia's Ministry of Education, is to create a visionary school in Malaysia, zero defects, and world-class education (Amin, 2018). Since its independence, Malaysia has accomplished many successes through the expansion of education and educational standards, particularly in terms of literacy and student participation (IAB, 2012). All schools, regardless of location, size and type, must provide excellent and comprehensive education to students (MOE, 2013). However, there are still substantial gaps in achievement between urban and rural schools, boys and girls, and socioeconomic backgrounds, contributing to an immense difference in educational equity (MOE, 2017b). High-quality education systems must provide the best education for every child, regardless of geography, gender or socioeconomic status (MOE, 2017a; Shannon \& Blysma, 2007). Schools, therefore, play a crucial role in ensuring that any change expected by the MOE translated into student incarceration (Institut Aminuddin Baki, 2017).

Researchers and organisations around the world have done a large number of school efficiency studies (Alm et al., 2018; Masci, Witte, \& Agasisti, 2016; Solomou \& Pashiardis, 2016). Based on the literature review of school efficiency, the theory of social system and social system theory as the main theories supporting school efficiency applied by most researchers (Scheerens 2013). Advances in the field of school efficiency research have created a range of opportunities for researchers to establish methods and models relevant to school effectiveness. Nonetheless, studies on effective school or school success are limited in 
Malaysia (Abdul Ghani et al., 2011). However, most researchers concentrated on the specific characteristics of effective schools and focused only on effective school leadership (Kondakci \& Sivri, 2014; Sani et al., 2013).

Abdul Ghani et al (2011) results from a study showed that the best schools in Malaysia and Brunei consistently adopt effective schooling practices as the educational environment progresses. The study also found that school leaders have a very significant and positive relationship with school development towards effective schooling. School principals have a critical role to play in enhancing schools and improving their performance towards highperforming schools (Bibi \& Kassim, 2011; Cheng \& Szeto, 2016; Sciarappa \& Mason, 2014). The principals' leadership is critical to contributing factors to the success of the school based on the results of the research. The appointment of principals based on of their seniority, regardless of leadership ability, skills, knowledge and experience, does not ensure that they can lead the school well. In other words, to be effective in leading a school, a leader must be chosen based on high leadership factors and be able to drive the school more effectively (Chua \& Zuraidah, 2014).

Besides, lyer, (2008) conducted a study to define the current situation of school efficiency characteristics in the Malaysian context from principals, department heads and school teachers. Research on 120 secondary school teachers and principals in Kuala Lumpur identified five useful attributes of the school, known as successful leadership, learning and teaching, cooperation between principals and teachers, understanding between principals and teachers, and active parent-teacher participation. The results of the study also found that the majority of schools in Kuala Lumpur are at the highest level of school performance and continue to practice school efficiency.

Malaysia's government seeks to boost the performance of primary and secondary schools (MOE, 2017). The ministry's goal is, therefore, to reduce the number of low-performance schools (MOE, 2017). However, the 2016 analysis of the Malaysian high school band found that almost $60 \%$ of Malaysian secondary schools ranked as low-level schools. This figure represents more than half of the total number of secondary schools in Malaysia. One of the government's attempts to enhance the performance and efficacy of the school in Malaysia is through coaching and mentoring. School wellbeing and effectiveness should be assessed in a comprehensive way, including all internal and external aspects of the school (Alm et al., 2019; Hajisoteriou et al., 2018). However, most researchers have focused only on student achievement and school achievement as school efficiency, while neglecting other factors closely related to school effectiveness (Samy \& Cook, 2009; Shannon \& Blysma, 2007). Therefore, the concept of school efficiency needs to be studied holistically, particularly in the primary aspect, such as the implementation of change in school.

Studies on the effectiveness of schools are one of many education reform initiatives that most countries around the world have taken to identify factors that influence school effectiveness (Lezotte \& Synder, 2011; Shannon \& Blysma, 2007). Moreover, school-effectiveness studies are still lacking in the context of education in Malaysia (Abdul Ghani et al., 2011; Abdul Karim, 1989; Baharak, 2015; Sani et al., 2013). The school effectiveness concept is broad and open, but most researchers focus purely on the achievement of the students. School achievement can be seen as a measure of the effectiveness of the school, while other factors are strictly related to school effectiveness (Samy \& Cook, 2009). Cultural change, which is a change of thinking and willingness to change among educators, is a significant obstacle to educational change (Amin, 2018). Leaders are actors of the changes which lead to a shift in school in an educational setting (Vandeyar, 2017). However, after SIPartners+ appointed in an educational 
environment, the role of principal changed. Without the support of others, a leader can not change (Loi et al., 2012). As a result, the willingness of the principals to change in receiving coaching and mentoring is a critical factor in the success of the planned change. Some principals found that they were unwilling to accept changes in school management, given that the presence of SIPartners+ in schools was an external factor in school administration (Kunalan, 2016; Tan, 2015). In addition, the lack of SIPartners+ experience in school management was also a factor in the absence of willingness to accept changes in-school among the principals.

\section{Relationship between Readiness for Changes and School Effectiveness}

Schools that are subject to changes from time to time, and schools also operate in changing environments actively (Campbell et al., 1997). The school leaders should, therefore, be prepared with any possibility that would transform the school in a better direction. The move is a process that all school administrators need to face; sometimes, they need to start the change and always respond to it (Al-Zyoud, 2015; Guskey, 2002). To ensure an ongoing transformation, the leader will be prepared to change between people (Azni et al., 2018; Erdoğan et al., 2014). In addition, the principal was claimed to determine the willingness to change his/her own in the current modernisation based on the numerous task requests and the constraints of the working environment (Everard et al., 2004). The qualitative study conducted by Zimmerman (2011) exploring the influence of the critical behaviour, their attitude to change, and preparation for change found that leaders should be prepared to make improvements by being self-practitioners who reflect and participate in professional learning.

Every change in the organisation has an impact on employee confidence and behaviour (Abdel-Ghany, 2014). The primary role of a school leader in education is an essential individual in the process of change. Consequently, the readiness of the Principals to change in receiving any new policies and policies is vital for ensuring the impact of changes to develop and the community of the school (Inandi \& Giliç, 2016). However, if they are not prepared and offer a negative view of the changes that will take place, they will respond to moves such as hesitation, anxiety, and attempts to undermine the attempts of the amendment made (Soumyaja et al., 2011). According to Azni et al (2018), one of the main factors was the main reason why the main fear of making changes was due to lack of information and the person suggesting the amendment was a lack of knowledge. Also, the teachers and staff rejected the changes, a power group that had an autonomous decline in transition, was comfortable with pre-existing conditions and failed according to the proposed movements. In the context of current change, coaching and mentoring is the new approach of MOE to school leaders to make the school more competitive and productive, and to improve the performance of the school towards high performance (Ng, 2017).

(Maimunah and Lewin (1993) agreed that the factors behind the school's effectiveness depend on the success of variables such as leadership, instructor, student and willingness to adapt. When an individual is ready to change, the changes are framed to be verified. However, if an individual or organisation is reluctant to be prepared to change, the planning of the changes will either be disrupted or will not be implemented. Therefore, to ensure the efficiency of this school, readiness is one of the critical factors to ensure that the planned process is accurate. Based on the discussion referred to above, the following hypotheses were proposed:

$\mathrm{H}_{1}$ : Appropriateness of change has a significant positive effect on school effectiveness. 
$\mathrm{H}_{2:}$ Management support has a significant positive effect on school effectiveness.

$\mathrm{H}_{3}$ : Change efficacy has a significant positive effect on school effectiveness.

$\mathrm{H}_{4:}$ : Personal valence has a significant positive effect on school effectiveness.

\section{Conceptual Framework}

This study consists of two main variables: the readiness to change as an independent variable and the efficiency of the school as a dependent variable. Readiness for change comprised of four primary constructs, namely the appropriateness of change, management support, change efficacy, and personal valence. At the same time, the nine dimensions of school effectiveness to be measured are vision, standards and expectations, leadership, collaboration and communication, alignment with standards, monitoring of teaching and learning, professional development, the learning environment and the involvement of families and communities. The School Effectiveness Dimension adopted by the High Performing School Model proposed by Shannon and Blysma (2007) while Holt et al (2007) were ready for change. The conceptual framework, illustrated as follows:

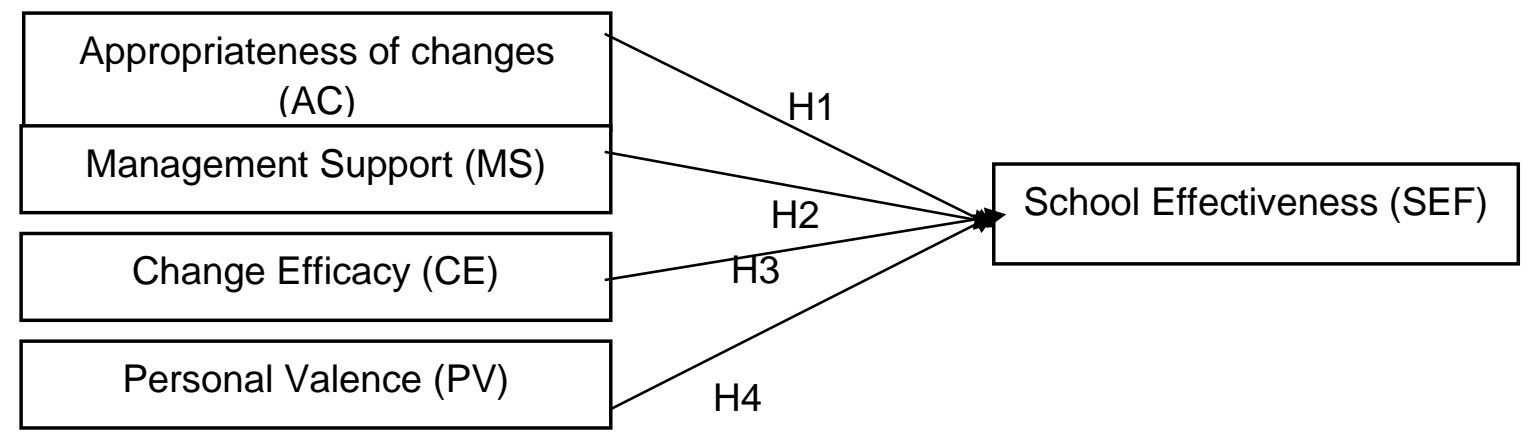

Figure 1. Conceptual framework

\section{Methodology}

This study is a cross-sectional survey. The study sample consisted of school principals in East Malaysia, with a total of up to 246 principals selected using a proportional stratified random sampling technique. The questionnaire Readiness for Organisational Change developed by Holt et al. (2007) was used. This instrument was designed to assess the readiness for change at the individual level because they believe that change activities are carried out by individuals within the organisation. Twenty-five items were included in the original questionnaire and adapted by the researcher to measure the level of readiness to change the principals when receiving SIPartners+ coaching and mentoring. Each item has five response options, indicating the 5-point Likert scale of the agreement. In 2007, Shannon and Bylsma developed a School Effectiveness Questionnaire (SEQ) instrument based on nine key features of high-performing schools. This tool contains 60 items of nine key dimensions

\section{Data Analysis}

The data were analysed using the Structural Equation Modelling (SEM) method and the AMOS tools applied. Structural Equation Modelling (SEM) is a second-generation multivariate statistical analysis technique developed to determine the relationship between different variables in the model (Hair et al., 2014). SEM uses are more authentication techniques than exploration techniques. SEM strength is the result of an analysis that combines authentication factor analysis, linear array regression, and route analysis. Following Anderson and Gerbing 
(1988), the proposed model was established using a two-stage structural equation model. Confirmatory factor analysis (CFA) performed first to estimate construct validity regarding convergent and discriminate validity. Next, we completed a path analysis to test the research hypotheses empirically. Today, the path-analytical procedure is becoming increasingly common in research studies.

\section{Findings and Results}

\section{Confirmatory Factor Analysis}

The Confirmatory Factor Analysis (CFA) was used in the measurement model to evaluate the appropriate model. Kline (2015) states that CFA is a statistical technique that considers whether the number of variable items in the variable meets the analytical requirements. Besides, the CFA also determines the extent to which the factor structure is capable of representing the covariant between the items and delete items that are not compatible with the variables. To ensure the built-in model achieves the targeted value, the load factor less than $0.50(<0.5)$ removed from the model. Three key CFA tests are to test model fit, convergent validity and construct reliability.

Essentially, there are three types of the goodness of fit (GOF) that are Absolute Fit, Incremental Fit and Parsimonious Fit. RMSEA, GFI, CFI and SRMR are among the appropriateness index regularly identified by researchers as Kline (2011). Nonetheless, Hair et al. (2014) suggest at least one compatibility index for each model's suitability category. Consequently, taking into account the most recent recommendations made by Hair et., (2014), researchers prescribe the use of four indicators as reported in the previous study; (i) Chi-Square $<5.00$, (ii) CFI $>0.90$, (iii) TLI $>0.90$ and (iii) RMSEA $<0.80$. Based on Figure 2, the GOF is shown to have achieved the proposed index as CFI $(0.915<0.90)$, TLI $(0.915<0.90)$, RMSEA $(0.067<0.08)$ and Chisq/df $(2.042<5.0)$.

In the CFA, there are three indicators to measure the convergent validity: the item reliability of each measure (factor loading); the reliability of each construct; and the average variance extracted (AVE). The constructs meet the convergent validity when the composite reliability (CR) exceeds the criterion of 0.70 and the average variance extracted (AVE) exceeds 0.50 (Hair et al., 2014). Table 2 shows the average variance extracted (AVE), the composite reliability (CR) and the Cronbach's alpha values. As in Figure 2, all item loadings are higher than 0.7. In addition, the minimum requirement was met by all AVEs and CRs. The results, therefore, support the convergent validity of the scales and all Alpha values are greater than 0.7, revealing excellent reliability (Tabachnick \& Fidell, 2013).

\section{Table 1. Results for the Measurement Model}

\begin{tabular}{|l|l|l|l|}
\hline Construct & AVE $>0.5$ & CR $>0.7$ & Alpha \\
\hline School Effectiveness & 0.547 & 0.927 & 0.925 \\
\hline Appropriateness of Change & 0.620 & 0.942 & 0.940 \\
\hline Management Support & 0.713 & 0.925 & 0.921 \\
\hline Change Efficacy & 0.607 & 0.902 & 0.900 \\
\hline Personal Valence & 0.905 & 0.966 & 0.963 \\
\hline
\end{tabular}




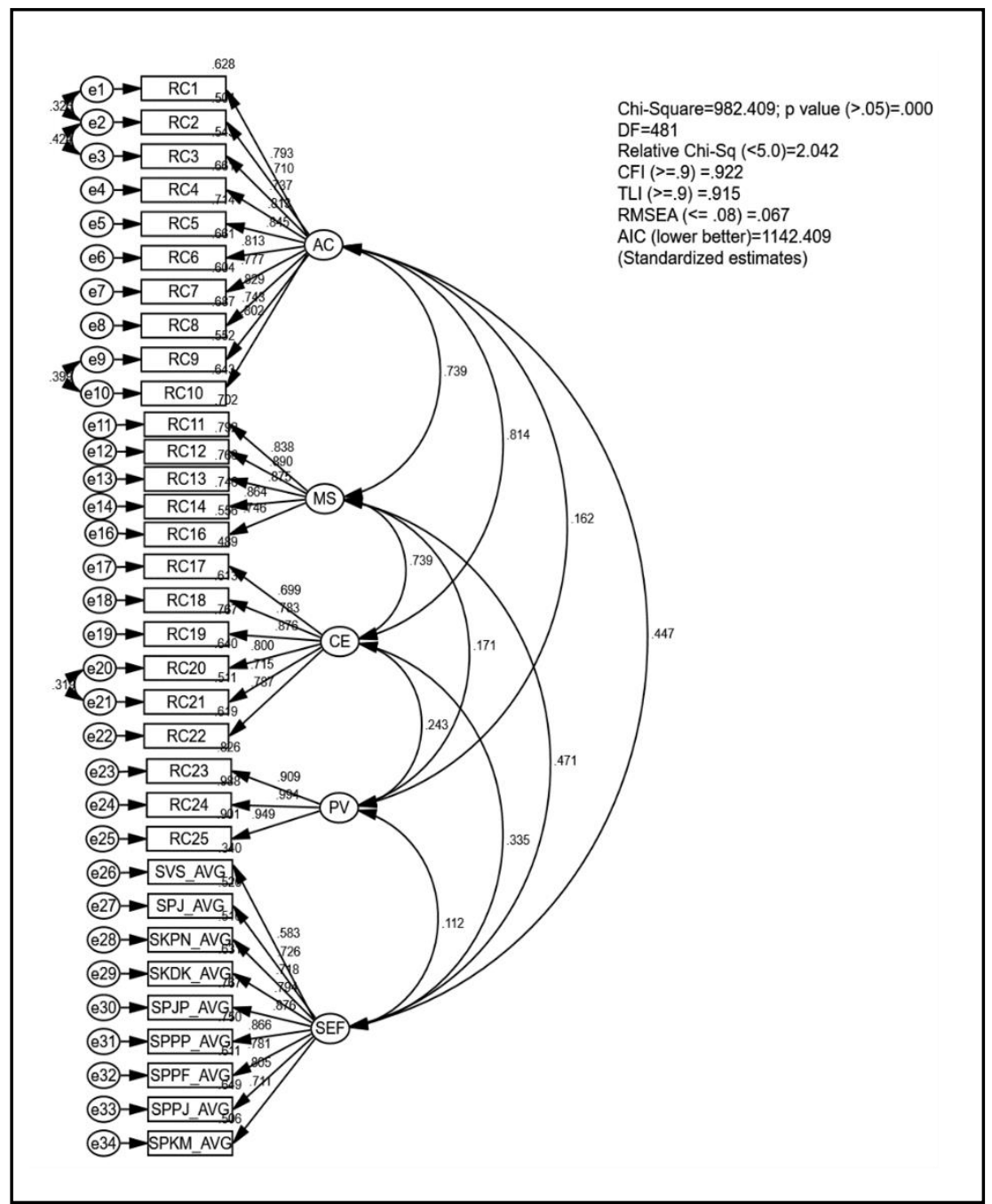

Figure 2. The Measurement Model

Discriminant validity refers to the extent to which the variable model of measurement is different and not closely related. One of the methods used to determine the discriminant validity is the reference to the value of the correlation between the variables (Byrne, 2010; Kline, 2015). In order to determine the model of measurement for the validity of the discriminatory criteria, the value of the correlation between the variables cannot be more than 0.90. An analysis of the correlation between variables finds that there is no problem associated with the discriminatory validity of which all the correlation between variables is less than 0.90 (see Table 2). As a result, the correlation value between 0.112 and 0.814 indicates that all research variables have achieved discriminatory validity and are not overlapping items between research variables.

Table 2: Discriminant Validity

\begin{tabular}{|l|l|l|l|l|l|}
\hline Construct & SEF & AC & MS & CE & PV \\
\hline School Effectiveness & $\mathbf{1}$ & & & & \\
\hline Appropriateness of Change & 0.447 & $\mathbf{1}$ & & & \\
\hline Management Support & 0.471 & 0.739 & $\mathbf{1}$ & & \\
\hline Change Efficacy & 0.335 & 0.814 & 0.739 & $\mathbf{1}$ & \\
\hline Personal Valence & 0.112 & 0.162 & 0.171 & 0.243 & $\mathbf{1}$ \\
\hline
\end{tabular}




\section{Structural Model}

The appropriateness of the data for the proposed model needs to be verified and evaluated after approval of the complete measurement model. The structural model analysis is carried out to test the direct relationship between independent variables, mediator and dependent variables. In this study, the structural model is used to determine the direct relationship between the appropriateness of change, management support, change of efficacy, and personal relevance to school effectiveness. Based on the measurement model, the overall review of the study as a whole was developed through a study. The final stage of the SEM analysis is to develop and evaluate a structural evaluation model based on the variables that have been evaluated, incomplete measurement models. The results of the structural model analysis, as shown in Figure 4.1, indicate the structural model that this study meets the requirements set for the fit model. Based on the structural model appropriateness index, the relative Chi-Sq value is $2.042(<=5)$, RMSEA is $0.067(<=0.08), \mathrm{TLI}$ is $0.915(>=0.9)$ and CFI is $0.922(>=0.9)$. In addition, the load factor value is also available above 0.50 as stipulated. As such, all criteria for model-appropriateness have been met and further analysis is conducted to determine the hypothesis.

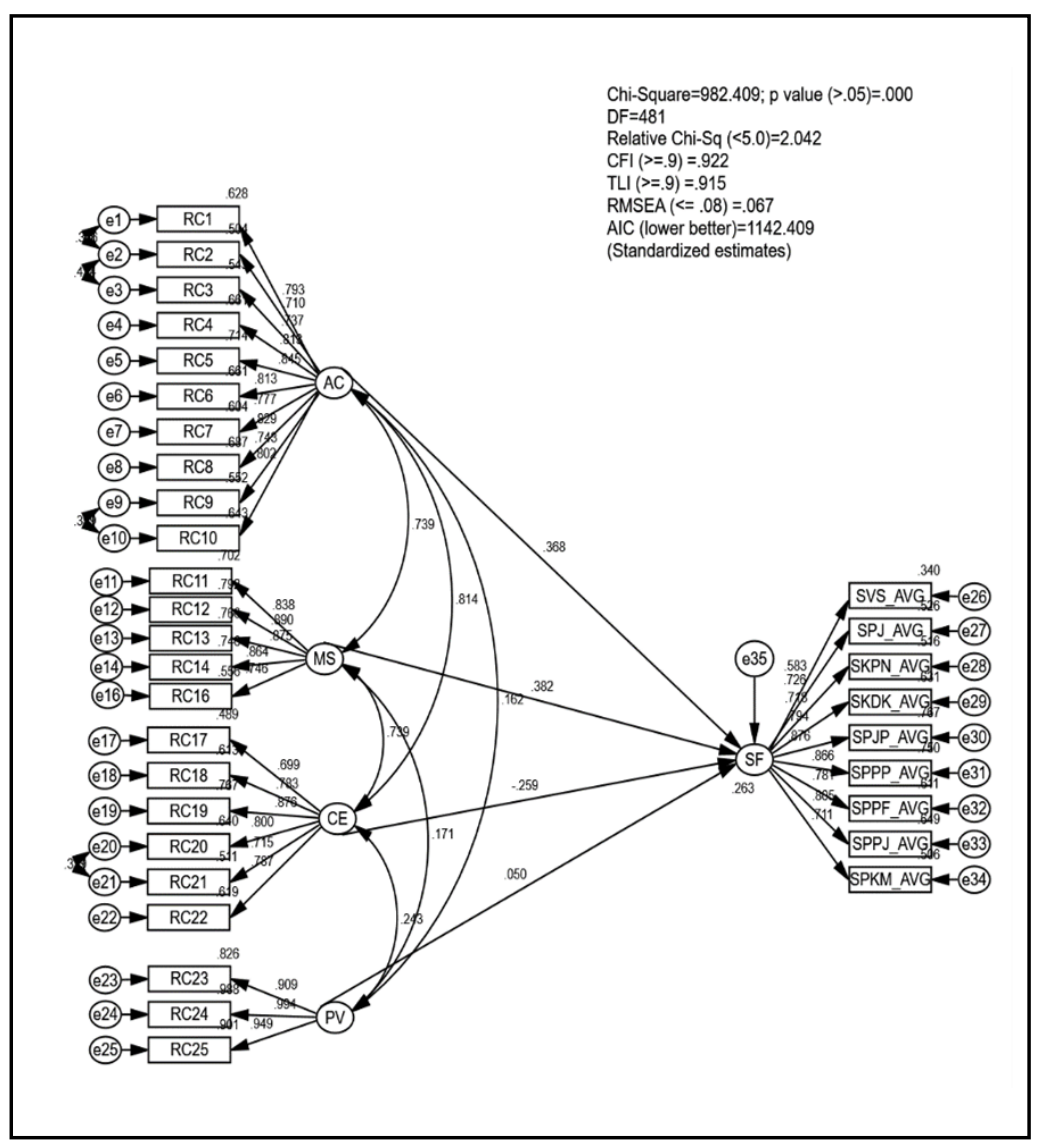

Figure 3. The Structural Model

As seen in Figure 3, the effectiveness of the school was estimated to be explained by $26.3 \%$ of the hypothesised model. It is important to stress that management support is a more reliable predictor of three factors. This result indicated that, once the principal has received management support, the changes will be implemented positively. Overall, two out of four hypotheses supported by the data. Appropriateness of change positively predicted school efficiency $(0.37, \mathrm{p}<0.006)$; therefore, $\mathrm{H} 1$ was supported. The second hypothesis was 
supported as management support significantly predicts the efficacy of the school $(0.372$, $p<0.000)$. In the meantime, changes in efficacy and personal valence have not significantly predicted school effectiveness, as shown in Table 3.

Table 3: Structural Model Result

\begin{tabular}{|l|l|l|l|l|l|}
\hline Path Analysis & S.E & $\beta$ & C.R & P & $\begin{array}{l}\text { Hypothesis } \\
\text { Result }\end{array}$ \\
\hline SEF - AC & .081 & .368 & 2.770 & $.006^{*}$ & Supported \\
\hline SEF ־ MS & .074 & .382 & 3.448 & $* * *$ & Supported \\
\hline SEF - CE & .081 & -.259 & -1.845 & 0.065 & $\begin{array}{l}\text { Not } \\
\text { Supported }\end{array}$ \\
\hline SEF - PV & .024 & .050 & 0.972 & 0.331 & $\begin{array}{l}\text { Not } \\
\text { Supported }\end{array}$ \\
\hline
\end{tabular}

\section{Discussion of Findings}

This study was carried out to determine the predictors of school effectiveness based on the readiness of the principal for change. The findings of this study focused on secondary school principals who work in low-performance schools. The result indicated that the Principals' readiness for change was at a high level. Based on the analysis, the appropriateness of change and support for management are predictors of school effectiveness. This situation shows that the principals are concerned about the changes in education that should benefit them so that they can help the school move forward. Also, as school administrators, principals need explicit confirmation of the improvements that will support them and the school in general (Vandeyar, 2017). This situation is driven by the change in the support system introduced by Malaysian Ministry of Education (Amin, 2018). In the context of Malaysian education, any changes made should be parallel to the mission and vision of the Ministry of Education to support the existing education system. Schools are subject to transition from inside and outside the educational environment (Campbell et al., 1997; Daly \& Milton, 2017). In the face of severe changes, school leaders need to be prepared for any possibility that will boost the school's situation (Kershner \& McQuillan, 2016). In order to succeed, leaders must develop a willingness to change among their subordinates (Azni et al., 2018; Woolner et al., 2014).

School leadership is adequately characterised by the characteristics of successful leaders and the perceptions of their teachers. Bush (2013) describes leadership in general as the influence of individuals to achieve goals shared by leaders and followers through the use of institutional, political, psychological and other resources. These aims represent the desired values and motivations and the needs, aspirations and hopes of leaders and followers alike. Leadership depends on the relationship and values held between leaders and followers (Deeboonmee \& Ariratana, 2014). Recent studies have shown that senior leadership plays a significant role in school development and improves student achievement (Azni, 2015). Effective principals with excellent leadership skills can continually improve school effectiveness levels (Riley et al., 2017). Other school leaders and district education officials should share good leadership experience in the management of school leadership and procedures to ensure consistency in school excellence. There is a positive relationship between school leadership and student achievement (Al-Harthi \& Al-Mahdy, 2017; Nir \& Hameiri, 2014; Wang et al., 2016).

Management support and appropriateness of change are the two most important factors. As the school administrator, management support factors play a crucial role in the school 
principal (Kondakci et al, 2015). Support from the top management and the management of the school itself to make any changes gives the principal a strong sense of direction for the school to be more productive and successful. Management support, therefore, plays a significant role in active school development in the process of change within the school (Zimmerman, 2006). The support of superiors has a substantial impact on the subordinates, particularly in the implementation of the change. The changes to be made must be consistent with the current situation and require the implementation of a sound work plan. In addition, the adaptability of the changes made also has a significant impact on subordinates. In the context of Malaysia's current education, any changes must be consistent with the Malaysia Education Blueprint, which aims to improve educational performance.

Moreover, the appropriateness of change also plays a vital role in the effectiveness of the school. The changes made need to have clear guidelines for the transition to be accepted by the principal or the school. Schools are exposed to change from within, and schools have a role to play in improving the environment (Campbell et al., 1997). In the face of extremely challenging changes, school leaders need to be prepared for any possibility that will make a better change in the school situation. Change is a repetitive process for school administrators to face. Leaders must develop a willingness to change among their subordinates to succeed (Azni, 2015; Woolner et al., 2014). The principals' readiness to change by accepting changes in the school is to influence the progress of the school. In addition, the readiness to change the principal in the school context is essential to the development of the school, as they are the leading leaders who will make changes to the school institutions. The effectiveness of the school also has a positive impact on the principal, as they are ready to receive the changes openly.

The readiness to change has a significant impact on schools in a variety of ways. Personal background and work-related issues are the main predictors that affect the readiness to change a person in the field of education as a study by İnandi and Giliç (2016). Each organisation must be prepared to ensure that the policy successfully adapted. In the context of education, teachers are the primary agents for change, which is the success of the change. Change is a linear process as it occurs on its own, and thus influences around it. A change in a person, either above or below, does not guarantee a meaningful change. The suitability of change refers to a person's experience in the face of potential changes. However, in the field of teaching, teachers often believe that they are prepared to change in response to specific reforms. Therefore, any changes in education should be taken into account the readiness to change of each teacher.

Changes in education pass through the start-up, implementation and formative stages. As a result, system education should evolve based on the value, belief and vision of the community and the ever-changing educational needs of the community (Kershner \& McQuillan, 2016). In the hierarchy of school administration, the Principal, as the Principal Leader of the school, should be sensitive to the most recent changes in education and be prepared to receive any changes made by the Ministry. Based on the context of this study, the school principal is ready to change by receiving coaching and mentoring SIPartners + , which has been established by the Ministry of Education. As a result, the readiness to improve the practice of coaching and mentoring SIPartners+ has a positive impact on the effectiveness of the school. Indirectly, the primary readiness for change at the time describes their support for government policies and policies to improve the country's education system through the Ministry of Education. In addition, the main readiness will be a positive indicator of the development of the education system, which is closely linked to the effectiveness of the school. 


\section{Conclusion}

This study was conducted to determine the extent to which constructs for readiness to change predicts school effectiveness. The changes in the context of this study were the implementation of the SIPartners+ policy in coaching and mentoring the principals. The findings of the study indicate the appropriateness of change and management support are able to influence the effectiveness of schools involved with the policy. It shows that when the principals believe that the implementation of the policy is relevant to the needs of the school and has the support of management at the district and state levels, then school effectiveness also improves. Therefore, every educational change that is implemented needs to be carefully planned, so that it meets the actual needs of the schools involved. The management at the middle level, namely the District Education Office and the State Education Department also need to understand the new policy philosophy that is being implemented and by giving positive support to the principals involved in the changes.

In conclusion, to ensure that every school achieves the vision established by the Ministry of Education, all parties need to work to ensure that the proposed changes are agreeable to everyone. In addition, a positive educational atmosphere can increase the incentive of teachers to work and build a high-performance school. Growing school organisation must be prepared to adapt in order to ensure the effective implementation of the policy. Teachers have become the key agents of change in the sense of education, which has been the success of a reform (Vandeyar, 2017). Transformation is linear as it happens in the individual and therefore affects the people around them. A change in the individual's own or lower level does not ensure significant change. Change suitability refers to a person's experience with possible changes. Nonetheless, teachers often believe that their willingness to change represents a response to specific reforms in the field of education. Therefore, a desire to change the knowledge of each teacher to achieve targeted objectives should be taken into consideration.

\section{References}

Abdel-Ghany, M. M. M. (2014). Readiness for change, change beliefs and resistance to change of extension personnel in the New Valley Governorate about mobile extension. Annals of Agricultural Sciences, 59(2), 297-303.

Abdul Ghani, M. F. (2008). Pembentukan Model Keberkesanan dan Penambahbaikan Sekolah. Unpublished PhD Thesis : Universiti of Malaya.

Abdul Ghani, M. F., Siraj, S., Razi, M. N., \& Elham, F. (2011). School effectiveness and improvement practices in excellent schools in Malaysia and Brunei. Procedia-Social and Behavioral Sciences, 15, 1705-1712.

Abdul Karim, M. N. (1989). Characteristics of effective rural secondary schools in Malaysia. Unpublished PhD Thesis :University of Wisconsin,Madison, United States.

Al-Zyoud, M. S. (2015). Educational leaders and the prospective responsiveness to the vast drastic educational changes in the Abu Dhabi emirate. International Education Studies, $8(2), 1-7$.

Ali Al-Harthi, A. S., \& Al-Mahdy, H. Y. F. (2017). Distributed leadership and school effectiveness in Egypt and Oman: an exploratory study. International Journal of Educational Management, 31(6), 801-813.

Alm, S., Låftman, S. B., Sandahl, J., Modin, B., De Witte, K., Schiltz, F., ... Modin, B. (2018). Effective schools, school segregation, and the link with school achievement. European Journal of Operational Research, 70(3), 464-484. 
Amin, S. (2018). Melangkah ke hadapan: Fokus dan Gerak Kerja Professional KPPM 2018 (Pertama, Vol. 1). Putrajaya: Firdaus Press Sdn. Bhd.

Anderson, J. C., \& Gerbing, D. W. (1988). Structural Equation Modeling in Practice: A Review and Recommended Two-Step Approach. Psychological Bulletin, 103(3), 411-423.

Anthony, D. P., \& van Nieuwerburgh, C. J. (2018). A thematic analysis of the experience of educational leaders introducing coaching into schools. International Journal of Mentoring and Coaching in Education, 7(4), 343-356.

Arivayagan, K. (2015). Teacher's perceptions related to principals' creative leadership practices towards school effectiveness. Unpublished Masters Thesis :Universiti Putra Malaysia.

Baharak, T. (2015). Transformational Leadership, Organizational Citizenship Behaviour and School Effectiveness in Primary Schools, Selangor, Malaysia. Unpublished PhD Thesis :University Putra Malaysia.

Bibi, J., \& Kassim, J. (2011). Instructional leadership and attitude towards organizational change among secondary schools principal in Pahang, Malaysia. Procedia-Social and Behavioral Sciences, 15, 3304-3309.

Bush, T. (2013). School Leadership in the 21st Century:Global Perspectives. Keynote Papers on 3rd Regional Conference on Educational Leadership and Management Instittue Aminudin Baki,Kuala Lumpur.

Byrne, B. M. (2010). Structural Equation Modeling with AMOS. In Structural Equation Modeling (Vol. 22).

Campbell, R. F., Corbally, J. E., \& Nystrand, R. O. (1997). Pengenalan Pentadbiran Pendidikan (Ketiga; A. R. M. A. Z. A. L. P. H. Elias, Ed.). Kuala Lumpur: Penerbit Universiti Putra Malaysia.

Cheng, A. Y. N., \& Szeto, E. (2016). Teacher leadership development and principal facilitation : Novice teachers' perspectives. Teaching and Teacher Education, 58, 140-148.

Chua, Y. P., \& Zuraidah, M. (2014). Predictors of multiple intelligence abilities for Malaysian school leaders. Procedia - Social and Behavioral Sciences, 116, 5164-5168. 3

Coleman, J. S. (1966). Equality of Educational Opportunity. Retrieved from http://www.eric.ed.gov/PDFS/ED012275.pdf

Davies, B., \& Ellison, L. (1997). Teachers ' perceptions of school quality and effectiveness : improving schools using staff attitude surveys. International Journal of Educational Management, 11(5), 222-228.

Day, C., \& Sammons, P. (2014). Successful school leadership: How successful school leaders use transformational and instructional strategies to make a difference.

Deeboonmee, W., \& Ariratana, W. (2014). Relationship between Strategic Leadership and School Effectiveness. Procedia - Social and Behavioral Sciences, 112(Iceepsy 2013), 982985.

Durlak, J. A., Weissberg, R. P., Dymnicki, A. B., Taylor, R. D., \& Schellinger, K. B. (2011). The impact of enhacing students' social and emotional learning: A meta-analysis of schoolbased universal interventions. Child Development, 82(1), 405-432.

Erdoğan, D. G., Güneş, D. Z., Alas, R., Vadi, M., Demirer, H., Bilgin, N., ... Zlatić, L. (2014). Organizational Justice, Optimism and Commitment to Change. Procedia - Social and Behavioral Sciences, 46(2), 34-41.

Everard, K. B., Morris, G., \& Wilson, I. (2004). Effective school management. In Effective School Management.

Fazel, P. (2013). Teacher-coach-student Coaching Model: A Vehicle to Improve Efficiency of 
Adult Institution. Procedia - Social and Behavioral Sciences, 97, 384-391.

Guskey, T. (2002). Professional Development and Teacher Change. In Teachers and Teaching (Vol. 8).

Hair, J. F., Black, W. C., Babin, B. J., \& Anderson, R. E. (2014). Multivariate Data Analysis. Pearson New International Edition, p. 758.

Hajisoteriou, C., Karousiou, C., \& Angelides, P. (2018). Successful components of school improvement in culturally diverse schools. School Effectiveness and School Improvement, 29(1), 91-112.

Hallinger, P., \& W.C Wang. (2015). The Evolution of Instructional Leadership. In Assessing Instructional Leadership with the Principal Instructional Management Rating Scale (pp. 1-23).

Harris, A., \& Bennet, N. (2001). School Effectiveness and School Improvement Alternative Perspectives. London: Continuum.

Harris, M. M., \& Willower, D. J. (2013). Principals' optimism and perceived school effectiveness. Journal of Educational Administration, 36(4), 353-361.

Hoy, W. K., \& Miskel, C. G. (2008). Educational Administration : Theory, Research and Practice (8th Editio). Boston Massacusetts: McGraw Hill Companies.

IAB, K. (2012). Buku Panduan Pengurusan Program SIPartner (Edisi Pert). Genting Highlands, Pahang: Institut Aminuddin Baki.

Inandi, Y., \& Giliç, F. (2016). Relationship of Teachers' Readiness For Change With Their Participation in Decision Making and School Culture. Academic Journal, 11(8), 823-833.

Institut Aminuddin Baki. (2017). Panduan Pelaksanaan Pendidikan Abad ke-21.

Iskandar, P., Foo, S. F., \& Ramli, B. (2018). Relationship between Senior Assistant of CoCurricular Leadership Styles and Secondary School Teachers'TM Job Satisfaction. International Journal of Academic Research in Business and Social Sciences, 7(14), 391402.

Ismail, I. A., Silong, A. D., Asmiran, S., \& Hassan, Z. (2011). Development of educational leadership in research university through community of practices among professors. Procedia - Social and Behavioral Sciences, 15, 828-832.

Iyer, M. G. (2008). Current views of the Characteristics of School Effectiveness in the Context of National Secondary Schools from the Perceptions of Principals, Heads of Department and Teachers in Kuala Lumpur, Malaysia. University of Leicester.

Kershner, B., \& McQuillan, P. (2016). Complex Adaptive Schools : Educational Leadership and School Change. International Journal of Complexity and Education, 13(1), 4-29.

Kline, R. B. (2015). Principles and Practice of Structural Equation Modeling (4th Editio). New York: The Guilford Press.

Kondakci, Y., Beycioglu, K., Sincar, M., \& Ugurlu, C. T. (2015). Readiness of teachers for change in schools. International Journal of Leadership in Education, 20(2), 176-197.

Kondakci, Y., \& Sivri, H. (2014). Salient characteristics of high-performing Turkish elementary schools. Journal of Educational Administration, 52(2), 254-272. 6

Kunalan, K. (2016). Pengaruh Bimbingan School Improvement Partner (SIPartner) Terhadap Pencapaian Sekolah: Kepimpinan Pengetua Sekolah Sebagai Mediator. Jurnal Pengurusan Dan Kepimpinan Pendidikan, 30(2), 55-71.

Lezotte, L. W., \& Synder, K. M. (2011). What effective schools do: Re-envisioning the correlates. Bloomington:Solution Tree Press.

Loi, R., Lai, J. Y. M., \& Lam, L. W. (2012). Working under a committed boss: A test of the relationship between supervisors' and subordinates' affective commitment. The 
Leadership Quarterly, 23(3), 466-475. https://doi.org/10.1016/j.leaqua.2011.12.001

Masci, C., Witte, K. De, \& Agasisti, T. (2016). Socio-Economic Planning Sciences The in fluence of school size, principal characteristics and school management practices on educational performance : An ef fi ciency analysis of Italian students attending middle schools. Socio-Economic Planning Sciences. https://doi.org/10.1016/j.seps.2016.09.009

$\mathrm{Ng}$, A. Y. M. (2017). School leadership preparation in Malaysia: Aims, content and impact. Educational Management Administration and Leadership, 45(6), 1002-1019.

Nir, A. E., \& Hameiri, L. (2014). School principals ' leadership style and school outcomes The mediating effect of powerbase utilization. Journal of Educational Administration, 52(2), 210-227.

Reynolds, D. (2010). School Effectiveness : Research, Policy and Practice. London: Routledge.

Riley, K., Montecinos, C., \& Ahumada, L. (2017). Effective principals serving in high poverty schools in Chile: managing competing realities. Procedia - Social and Behavioral Sciences, 237(June 2016), 843-849.

Sammons, P., Gu, Q., Day, C., Ko, J., \& Sammons, P. (2011). Exploring the impact of school leadership on pupil outcomes and effective schools in England.

Samy, M., \& Cook, K. (2009). Perceived school effectiveness: Case study of a Liverpool college. International Journal of Educational Management, 23(2), 185-198.

Sani, M., Zabidi, A., Razak, A., \& Banu, H. (2013). Smart Principals and Smart Schools. Procedia - Social and Behavioral Sciences, 103, 826-836.

http://www.ibo.org/globalassets/publications/ib-research/continuum/what-is-effectiveschooling-report

Schweinberger, K., Quesel, C., Mahler, S., \& Höchli, A. (2017). Effects of feedback on process features of school quality: A longitudinal study on teachers' reception of school inspection of Swiss compulsory schools. Studies in Educational Evaluation, 55(June), 7582.

Shannon, S., \& Blysma, P. (2007). Nine Characteristics of High-Performing Schools: A researchbased resource for schools and districts to assist with improving student learning. Washington: Superitendent Of Public Instruction.

Sharifah, M. N. (2010). Keberkesanan Sekolah: Satu Perspektif Sosiologi (Cetakan Ke). Serdang: Penerbit Universiti Putra Malaysia.

Sharifah Maimunah, S. Z., \& Lewin, K. . (1993). Insights into science education: Planning and policies in Malaysia. Paris.

Shih, W., \& Tsai, C. (2016). The effects of knowledge management capabilities on perceived school effectiveness in career and technical education. Journal of Knowledge Management, 20(6), 1373-1392.

Simendinger, E., Gonzalez-perez, M. A., Crawford, J., Thomason, S., Reynet, P., Kjellander, Gonzalez-perez, M. A. (2017). Teaching effectiveness attributes in business schools. International Journal of Educational Management, 31(6), 780-800.

Solomou, G. N., \& Pashiardis, P. (2016). An effective school autonomy model: Examining headteachers ' job satisfaction and work-related stress. International Journal of Educational Management, 30(5), 718-734.

Soumyaja, D., Kamalanabhan, T. J., \& Bhattacharyya, S. (2011). Employee Readiness to Change and Individual Intelligence: The Facilitating Role of Process and Contextual Factors. International Journal of Business Insights \& Transformation, 4(2), 85-91.

Tabachnick, B. G., \& Fidell, L. S. (2013). Using Multivariate Statistics. In Pearson Education (Sixth Edit). 
Tan, S. Y. (2015). Pelaksanaan Program SIPartners+ di Negeri Johor. Universiti Teknologi Malaysia.

Trujillo, C. (2018). Effective Leadership Attributes and Coaching Model for Principals. Northern Arizona University.

Vandeyar, S. (2017). The teacher as an agent of meaningful educational change. Kuram ve Uygulamada Egitim Bilimleri, 17(2), 373-393.

Wang, L. H., Gurr, D., \& Drysdale, L. (2016). Successful school leadership : case studies of four Singapore primary schools. Journal of Educational Administration, 54(3), 270-287.

Zimmerman, J. (2011). Principals preparing for change: The importance of reflection and professional learning. American Secondary Education, 39(2), 107-114. 